\title{
Continuity of care for children with special healthcare needs during the COVID-19 pandemic
}

\author{
Continuidade do cuidado às crianças com necessidades especiais de saúde durante a pandemia da COVID-19 \\ Continuidad del cuidado a los niños con necesidades especiales de salud durante la pandemia de COVID-19
}

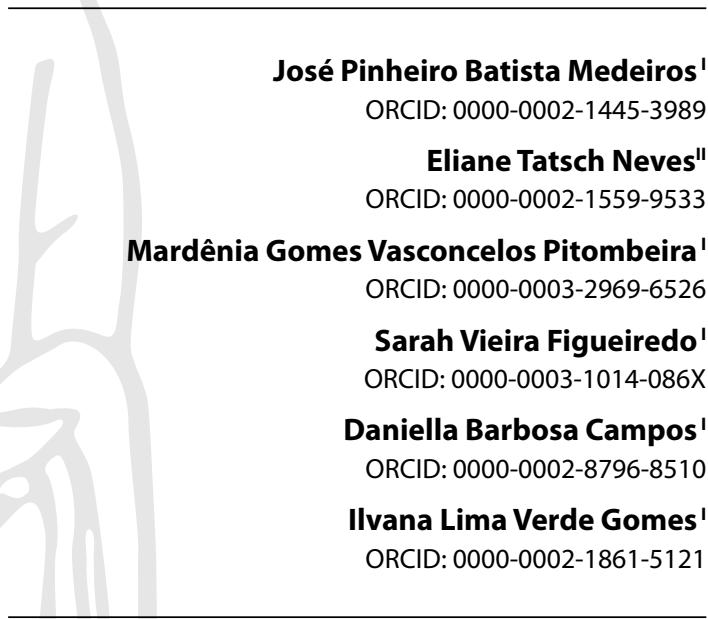

'Universidade Estadual do Ceará. Fortaleza, Ceará, Brazil. "Universidade Federal de Santa Maria. Santa Maria, Rio Grande do Sul, Brazil.

How to cite this article:

Medeiros JPB, Neves ET, Pitombeira MGV, Figueredo SV Campos DB, Gomes ILV. Continuity of care for children with special healthcare needs during the COVID-19 pandemic. Rev Bras Enferm. 2022;75(2):e20210150 https://doi.org/10.1590/0034-7167-2021-0150

Corresponding author: José Pinheiro Batista Medeiros E-mail: josemedeiro@hotmail.com

EDITOR IN CHIEF: Antonio José de Almeida Filho ASSOCIATE EDITOR: Hugo Fernandes

Submission: 03-24-2021

Approval: 04-21-2021

\begin{abstract}
Objective: To describe the continuity of care for children with special healthcare needs during the COVID-19 pandemic through the perception of their caregivers in the Northeast of Brazil. Methods: Qualitative descriptive-exploratory research carried out between June and September 2020, in a municipality in the Northeast of Brazil. Eleven caregivers participated through semi-structured interviews conducted at home. The data were submitted to thematic content analysis. Results: The social isolation period and the suspension of health services affected the continuity of care, configuring the category "Implications of the COVID-19 pandemic for the continuity of care". Caregivers expressed fear of children contracting the coronavirus, characterizing the category "Fears and uncertainties of the COVID-19 pandemic in view of the vulnerability of children with special healthcare needs". Final considerations: Caregivers' reports revealed problems in the continuity of care for the studied cohort. Therefore, health care practices must be rethought in times of pandemic.

Descriptors: Continuity of Patient Care; Child Care; Chronic Disease; Children with Health Issues; COVID-19.
\end{abstract}

\section{RESUMO}

Objetivo: Descrever a continuidade do cuidado às crianças com necessidades especiais de saúde durante a pandemia da COVID-19, na percepção de suas cuidadoras no interior do Nordeste brasileiro. Métodos: Pesquisa qualitativa descritivo-exploratória realizada entre junho e setembro de 2020, em município do Nordeste brasileiro. Participaram 11 cuidadoras por meio de entrevistas semiestruturadas realizadas no domicílio. Os dados foram submetidos à análise de conteúdo temática. Resultados: Período de isolamento social e suspensão dos serviços de saúde afetaram a continuidade do cuidado, configurando a categoria "Implicações da pandemia da COVID-19 para a continuidade do cuidado". As cuidadoras expressaram medo de a criança contrair o coronavírus, caracterizando a categoria"Medos e incertezas da pandemia da COVID-19 diante da vulnerabilidade das crianças com necessidades especiais de saúde". Considerações finais: Os discursos revelaram problemas na continuidade do cuidado do público estudado. Portanto, as práticas de atenção à saúde devem ser repensadas em tempos de pandemia. Descritores: Continuidade da Assistência ao Paciente; Cuidado da Criança; Doença Crônica; Crianças com Deficiência; COVID-19.

\section{RESUMEN}

Objetivo: Describir la continuidad del cuidado a niños con necesidades especiales de salud durante la pandemia de COVID-19, en la percepción de sus cuidadoras en municipio del Nordeste brasileño. Métodos: Investigación cualitativa descriptiva-exploratoria realizada entre junio y septiembre de 2020, en municipio del Nordeste brasileño. Participaron 11 cuidadoras por medio de entrevistas semiestructuradas realizadas en domicilio. Datos fueron sometidos al análisis de contenido temático. Resultados: Período de aislamiento social y suspensión de servicios de salud afectaron la continuidad del cuidado, configurando la categoría "Implicaciones de la pandemia de COVID-19 para la continuidad del cuidado". Cuidadoras expresaron miedo al niño contraer el coronavirus, caracterizando la categoría "Miedos e incertidumbres de la pandemia de COVID-19 delante de la vulnerabilidad de los niños con necesidades especiales de salud". Consideraciones finales: Discursos revelaron problemas en la continuidad del cuidado del público estudiado. Así, las prácticas de atención de salud deben ser repensadas en tiempos de pandemia.

Descriptores: Continuidad de la Atención al Paciente; Cuidado del Niño; Enfermedad Crónica; Niños con Discapacidad; COVID-19. 


\section{INTRODUCTION}

The COVID-19 pandemic began in China at the end of 2019 and spread rapidly across all continents. The outbreak of the new coronavirus was declared a global public health emergency by the World Health Organization (WHO) on January 30, 2020; and, on February 3, 2020, Brazil declared COVID-19 a national public health emergency ${ }^{(1-2)}$.

COVID-19 is a severe acute respiratory infection caused by SARSCoV-2 and has a high contagion capacity ${ }^{(3)}$. The acute respiratory syndrome caused by the new coronavirus has affected all age groups, causing everything from mild symptoms to severe respiratory conditions. Symptoms generally include fever, cough, nasal congestion, runny nose, sore throat and, when not treated properly, can progress to severe acute respiratory syndrome or respiratory failure ${ }^{(1)}$.

The COVID-19 pandemic has presented itself as one of the greatest health challenges on a global scale in this century ${ }^{(2-3)}$, especially among individuals with chronic diseases who need continued monitoring by health services.

In this scenario, there are Children with Special Healthcare Needs (CSHCN), that is, those who have or are at increased risk of developing a physical, developmental, behavioral, or emotional dysfunction and who require health services in excess of that usually required by children in general ${ }^{(4)}$.

Thus, the restrictions imposed by the pandemic have intensified the range of difficulties faced by $\mathrm{CSHCN}$, since they are a cohort more prone to infections due to an unstable immune system, due to their frequent visits to health services (especially medical emergencies), and the higher prevalence of comorbidities among them ${ }^{(5)}$.

Thus, the search for care for CSHCN represents a challenge for the health system, as it is a clientele that suffers recurrent hospitalizations/readmissions and that, many times, has its state aggravated by the absence of adequate guidelines for care in the post-discharge period ${ }^{(6)}$. Continuity of care is a fundamental issue for $\mathrm{CSHCN}^{(7)}$ and has presented itself as an additional challenge for caregivers during the pandemic, requiring, therefore, that health professionals and managers develop strategies to mitigate the consequences of health care restrictions imposed on these children.

In this sense, given the dimension and complexity of the theme, this study was guided by the following research question: How has the continuity of care been handled for children with special health needs in the context of the COVID-19 pandemic in the interior of Brazil?

\section{OBJECTIVE}

To describe the continuity of care for children with special healthcare needs during the COVID-19 pandemic through the perception of their caregivers in the Northeast of Brazil.

\section{METHOD}

\section{Ethical aspects}

This study was approved by the Human Research Ethics Committee of the Universidade Estadual do Ceará [State University of Ceará] in 2020. All participants signed the Free and Informed
Consent Form (ICF). The ethical precepts for research involving human beings were respected according to Resolution No. 466/12 of the National Health Council. To maintain anonymity, caregivers were attributed flower names.

\section{Study type}

Qualitative research of the descriptive-exploratory type. The qualitative approach was chosen because it focuses on the study of relationships, representations, opinions, and perceptions of human interpretative production, seeking to understand the intrinsic reality in which the subject is inserted and what meaning he attributes to that way of living. In this type of study, the researcher investigates the universe of the individual considering his environment, beliefs, values, relationships, and behaviors in light of life situations ${ }^{(8)}$.

In order to guarantee the validity of methodological aspects, this article followed the recommendations of the Consolidated Criteria for Reporting Qualitative Research (COREQ) ${ }^{(9)}$.

\section{Study scenario}

The research was carried out from June to September 2020, in an inland city of the Brazilian Northeast. It is part of the coverage area of $8^{a}$ Coordenadoria Regional de Saúde (8a CRES) [8th Regional Health Coordination] of the State of Ceará. Its population estimate is of 26,469 inhabitants, with 10,763 inhabitants (40.7\%) in rural areas and 15,706 (59.3\%) in urban areas. It is located 273 $\mathrm{km}$ from the state capital, Fortaleza, and has a Human Development Index (HDI) of 0.619, considered average ${ }^{(10)}$.

Currently, it has 11 Family Health Units registered in the Cadastro Nacional de Estabelecimentos de Saúde (CNES) [National Registry of Health Establishments] and distributed at the headquarters and in six districts. The municipality also has: a municipal hospital (general hospital), which services spontaneous and referenced demand; and a Psychosocial Care Center - CAPS I ${ }^{(11)}$.

\section{Study participants}

The study counted with the participation of 11 CSHCN caregivers registered in a physiotherapy rehabilitation center in the city where the study occurred. The inclusion criteria were: to be one of the main responsible parties for monitoring the child in health services and at home; be over 18 years old; and being a caregiver for children up to 12 years old ${ }^{(12)}$. Exclusion criteria were: caregivers who were unable to articulate thought and speech, not being understood at the time of the interview by the interviewer; and an impossibility of carrying out the home visit due to not finding the participant's contact address or telephone number. All caregivers who had CSHCN undergoing physical therapy at the rehabilitation center were invited to participate in the study, and only one was not included, as it was not possible to keep in touch due to outdated phone and address information in the medical record.

\section{Data collection and organization}

The data were collected in the households through a semistructured interview script composed of sociodemographic 
questions and questions related to the theme. For each caregiver, the following guidance was given: "Talk about how your child's health has been monitored during the COVID-19 pandemic."

Data collection took place between the months of June and September 2020. The interviews were all conducted by the main researcher, the first author; they lasted an average of 30 minutes and were recorded on digital audio media. The empirical material obtained from the interviews was transcribed in full and organized in individual files for further analysis.

As a consequence of the COVID-19 pandemic, caregivers were not attending the rehabilitation center. Therefore, the initial contact with this audience took place by telephone or messaging application. If they agreed to participate in the interview, the researcher would go to the caregiver's residence to collect data at previously scheduled times and days that best suited the participants.

Due to the ongoing pandemic, all sanitary measures and precautions were observed (such as wearing a mask, face shield, Alcohol-based hand sanitizers and distancing) for safe data collection, aiming to preserve the health of the caregiver, the child, and the researcher, according to Brazilian Ministry of Health and Comissão Nacional de Ética em Pesquisa (CONEP) [National Research Ethics Commission] guidelines.

\section{Data analysis}

The data were analyzed by means of thematic content analysis proposed by Bardin, which presents a set of communication analysis techniques, articulating the way to explore some written materials and seeking to characterize the main concepts or themes addressed in a text. In this method, the investigation aims at the objective, systematic, and quantitative description of the content manifested in the communication ${ }^{(13)}$.

The method proposed by Laurence Bardin is developed around three chronological poles: pre-analysis; material exploration; and treatment of results with subsequent inference and interpretation $^{(13)}$. For analysis operationalization, after exhaustive reading of the transcripts of the interviews (pre-analysis), analytical tables were used in which the clippings of participants' speeches/reports were organized according to the identified themes (material exploration); from that point on, the thematic categories (treatment of results) were organized. Subsequently, inference and interpretation occurred with the use of scientific literature to discuss the data.

After analyzing the data, two thematic categories were elaborated: Implications of the COVID-19 pandemic for continuity of care; and Fears and uncertainties of the COVID-19 pandemic in light of the vulnerability of CSHCN.

\section{RESULTS}

Of the 11 caregivers participating in this research, nine were mothers and two were grandmothers. The age varied between 18 and 54 years, with an average of 33 years. The average household income was $\mathrm{R} \$ 1,360.00$, and only one caregiver reported not receiving the Continuous Installment Benefit (BPC), with a monthly income of only $\mathrm{R} \$ 500.00$. As for their occupation, ten caregivers stated that their main functions were to take care of the child and carry out household chores. The level of education showed that only one caregiver had completed higher education and another, high school; the rest had not finished high school. Regarding the CSHCN, the age varied between 3 to 11 years, seven were male and four, female. All had demands for medication care, modified usual care, and neurodevelopment care and only one used technological care (tracheostomy and gastrostomy).

In this study, we show that the services most used by CSHCN were specialized services, such as physiotherapy, in the studied municipality; and consultations with specialists, in establishments in other municipalities in the state's health network.

\section{Implications of the COVID-19 pandemic for continuity of care}

In this study, the caregivers reported that this period of social isolation and interruption of health services was difficult for the continuity of care for CSHCN, as there were missed consultations, tests, and physiotherapy sessions that would have been crucial for the development and better quality of the children's life.

[...] this year as well, due to this pandemic, I didn't even try to take him [for a consultation], nor make an appointment for him, which was supposed to be with the neuro [neuropediatrician] it was supposed to be Tuesday, I didn't take him either; I will have to reschedule, because it is difficult for you to go out with a child in the middle of a pandemic like this. (Hortensia)

[...] There were tests scheduled for him to do there at SARAH [Sarah Kubitschek Hospital], then everything was canceled, and the physical therapies were stopped. (Tulip)

[...] everything stopped, especially her physical therapies. The other consultations are all canceled [...]. (Camellia)

One of her consultations was in February. We took her to a nephrologist; and, since then, she has been removed from the nephrologist, neuropediatrician, geneticist, pediatrician, and from physiotherapy. Her treatment in Fortaleza was interrupted entirely; I continued on caring the way I was doing before, giving her medications normally, but the consultations really, she didn't attend them. (Iris)

The biggest demand that we had, which we were unable to change yet, was the tracheostomy that was supposed to be changed early in the year, but, due to this pandemic, they did not resolve it. (Jasmine)

All CSHCN in this study are monitored by the health network services and, after the announcement of the restrictive measures, the caregivers had to interrupt the care that was already underway.

There was no way to finish his follow-up because of this COVID-19 [...] The tube change [gastrostomy] was interrupted, the hospital is packed with contaminated people; I even went there to have his tube changed, and there were many infected people already there, then we still managed to reschedule an appointment there, which was already overdue. (Jasmine)

The pandemic revealed new forms of care that are useful for orienting caregivers during isolation: teleconsultations. 
Her consultation at SARAH was done over the phone, because they thought it best not to risk taking her there. So her pediatrician, from there, called and made the consultation by phone and said that after this pandemic outbreak passed, and if we wanted to reschedule an in-person consultation, she could go. (Iris)

[...] they said that the location was almost at a complete halt, and they were not receiving anyone, instead, they keep calling us and providing some guidance. (Azalea)

Thus, although it is a period of great uncertainty, it is necessary that priority groups be protected, given the fragility of their health conditions. The adoption of strategies by health services, such as guidance through teleconsultations, should be increased in order to protect the CSHCN from the virus infection, since, for the caregiver to leave a municipality within the interior of the state (where the rate of infection by the coronavirus is smaller) for the state capital (where the infection rate is higher), is a great challenge and one of the factors that have caused anguish and fears.

\section{Fears and uncertainties of the COVID-19 pandemic in light of the vulnerability of CSHCN}

In their testimonies, the caregivers expressed fears and uncertainties about the fragile health of the CSHCN, as they believe that, if the child contracts the virus, it could lead to serious complications due to their comorbidities. Caregivers are aware of the importance of follow-ups in health services for the evolution of the child's clinical condition, however, given the transmissibility power of the coronavirus, they are afraid that the child may contract it and have their health situation worsened.

Another caregivers' concern, revealed in their narratives, is that, in a post-pandemic period, in a "new normal", children will have difficulties adapting to this new reality, in which social distancing and preventive measures, such as the use of masks for children, are still needed.

Now, on the 31st, I went to a consultation with the neuro [neuropediatrician] in Fortaleza, I was scheduled at the HGF [Hospital Geral de Fortaleza 'Fortaleza General Hospital'], then I said "Oh, my God, I'm going, but I'm scared to death", but I went. (Camellia)

My biggest fear, the biggest challenge for [child's name], is that he has problems, of still feeling a lot of seizures, even though he's taking the medications, then my fear was of just that, of him getting corona and harming himself and not resisting. (Azalea)

The fear I had was of taking him, both to appointments and to physiotherapy, and that he would end up contracting the virus, taking into account that his immunity is low and also because of the five crises of respiratory infections that he has already had. Then I was very, very afraid, and to this day I still am of taking him wherever he has to go, because I am very afraid of contagion. (Hortensia)

Some caregivers chose not to take CSHCN to health services at the height of the first wave of COVID-19, between May and July 2020 , because they feared that they could contract the disease, as this public has risk factors and several comorbidities that can worsen the prognosis related to infection with the new coronavirus.

[...] we are afraid [of the pandemic]. I have restricted my visits to physiotherapy because of that. I was afraid to take her, so I reduced the physiotherapy visits. (Lily)

The main difficulty in this pandemic was the removal of [child's name] from treatment as a whole. And some of her appointments were canceled and those that were not, I thought it was feasible not to take her, really out of fear for her, fear of us who care for her, so we thought it best to seclude her, leave her be at home, do what had to be done to try to take care of her the best way. (Iris)

Right at the beginning of the pandemic, I stopped taking her to the doctors, because I was very afraid; to this day, I still fear that she will get a serious disease, because I know she would not be able to bear it, so I stopped going because of fear, that's why. (Melissa)

[...] we even missed an appointment he had, in Fortaleza, with the neuropediatrician, and the physiotherapy, which I also stopped taking him because of the pandemic. (Hortensia)

All the exams, her appointments, everything was canceled, then when services started to come back, they started calling us, so I went to all consultations [...] we are afraid... you have to, you know, carry on with that fear, and avoiding many things. (Camellia)

Given the vulnerability resulting from chronic diseases in these children, caregivers need to be in constant contact with health services; therefore, going back to some face-to-face consultations, despite the fear of infection.

Caregivers also revealed, in their narratives, fear of worsening of the health status of CSHCN for being so much time away from health services, or even fear of the child having a setback in the gain of neuropsychomotor development acquired prior to the pandemic

And the fear is that it may delay his development, all this time he spent without follow-ups, without physical therapy, he may lose what he has already evolved. (Amaryllis)

Thanks to God [child's name] is in good health, but, in matters of actual treatment with the specialist, we are concerned, because they are serious problems, that, from being a long time away from the doctor, we are afraid of aggravation. (Iris)

In the caregivers' reports, uncertainties emerged as to how the children will face reality in a future scenario in which the virus will continue to circulate.

And his risk, of going back to normal activities, is of getting COVID, because he can't use his mask for a long time, as he loses his breath, he doesn't know how to breathe properly, because he has that spongy flesh on his nose. So, it is very difficult for him to be wearing a mask, so that is my fear of him returning to normal activities, physiotherapy, school, his appointments and everything. (Daisy)

[...] and, also, in relation to the appointment that has already been rescheduled and has occurred, I already took him to Fortaleza and I am about to take him again, but always with great care. (Hortensia) 
The need to continue health treatments, even midst pandemic, causes fear in caregivers, as it implies difficulties in having the children use the mask and the need to distance themselves from health services. It is noticed that the caregivers are faced with a dilemma, as they know that the child cannot stay long without health service monitoring, but they also understand that the travel to the appointment may increase the risk of contamination.

\section{DISCUSSION}

The COVID-19 pandemic has presented itself as a major challenge for CSHCN, considering the high vulnerability of this cohort's health conditions. The interviewed caregivers reported difficulties in giving continuity to health care, because, in addition to the interruption of most appointments by health services, they fear for the fragile health and risk of contamination of these children.

Maintaining care for chronic patients has been a challenge throughout the interplay of the pandemic. Social isolation, which is essential to reduce contamination by the virus, by itself, leads to several consequences that can aggravate existing diseases. In this pandemic period, the health system had to suspend most of the elective consultations and health monitoring of the population with chronic diseases, including CSHCN. These measures were essential to contain the spread of the virus and protect individuals, however, they resulted in implications for the continuity of treatments.

The continuity of care is related to a specific health problem and the succession of events between one consultation and another, as well as the information transfer mechanisms that support decisions regarding the treatment of the patient ${ }^{(14)}$. Continuous and coordinated care is an indispensable factor for CSHCN and must be offered considering their needs ${ }^{(7)}$. As during the COVID-19 pandemic, families are at risk of being left alone to care for their children, continuity of care should be a health service priority ${ }^{(15)}$.

However, the present study cohort has faced significant disruptions in the continuity of care, and this can have consequences, such as worsening health conditions, impairments in neuropsychomotor development with the interruption of rehabilitation services, and increased caregivers' fears and uncertainties (in this research, grandmothers and mothers) in the absence of information and necessary guidance for providing home care to CSHCN.

This study validates a reality experienced in the global context, in which the mitigation strategies adopted by many countries to limit the spread of the coronavirus include the reduction or complete closure of rehabilitation units and centers, with the consequent interruption of rehabilitation programs. As a result, fragile individuals with severe neurodevelopmental conditions, especially children and their parents, are at risk of being alone and without supervised rehabilitation support ${ }^{(16-17)}$.

In this perspective, the pandemic imposed challenges at different levels of care within the health services and significantly impacted the health care of people with chronic diseases and the continuity of their treatments, among which are the CSHCN. Self-care and prevention measures aimed at individual and collective protection are essential, as they contribute to reducing the likelihood of the disease reaching vulnerable groups and, in turn, reduce morbidity and mortality rates $^{(18)}$.
The grandmothers and mothers of this research have faced fears, uncertainties, and are distressed because they feel powerless in the face of a situation that is beyond anyone's control. A recent study reveals that caregivers are walking in unfamiliar territory and are experiencing extraordinary levels of uncertainty, family upheaval, and fear. Support for families during this period will need to reflect the vulnerability of some groups. Although there are risks inherent to the pandemic, the paths to resilience are also extremely important ${ }^{(19)}$.

In this study, caregivers reported important difficulties with the interruption of health monitoring, since this public has multiple chronic conditions, functional limitations, reliance on medical technology, in addition to the need for a complex network of health service providers. Thus, interruptions in the attendance of these services can have consequences for the child's development.

Corroborating the results of this research, an Italian crosssectional study highlights the burden of stress and fears faced by caregivers of children with neurodevelopmental disabilities during the pandemic. It was evidenced that the risk of emotional and psychological overload for the parents was especially high for the families of CSHCN. The psychological symptoms of caregivers were associated with concerns about child development during social isolation, and the main concerns were related to the risk of contagion from COVID-19 and damage to child development due to the suspension of rehabilitation services ${ }^{(15)}$.

According to the literature, children with developmental disabilities have greater health care access barriers due to an inadequate number of specialists, socioeconomic vulnerabilities, complex medical comorbidities, and barriers in geographical distances.

In the midst of the pandemic, this public requires specific attention to minimize the consequences of the interruption of care in essential services. These children are especially vulnerable to the effects of the pandemic, as they have greater health needs compared to children of typical development, and the consequences of missed opportunities, today, will only be evident in the coming years ${ }^{(20)}$.

In the present investigation, some caregivers reported not taking the CSHCN to their appointments, tests, and physiotherapy for fear that they would contract the coronavirus. A qualitative Australian study corroborates our results by showing that parents avoided taking their children with disabilities to health treatments for fear of contamination. However, these caregivers felt distressed because they were missing a window of opportunities for the child's development. Therefore, this shows that the impact of the pandemic can be felt more intensely in people with disabilities and their caregivers ${ }^{(21)}$.

The evidence found in this study agrees with an investigation carried out in British Columbia, Canada, where $30.3 \%$ of parents of children with medical complexities avoided taking them to the emergency room during circumstances in which they would normally have done it. There, $63.8 \%$ of children had their appointments with specialists canceled or postponed, and most children had reduced or interrupted rehabilitation therapies (occupational therapy, physiotherapy, and speech therapy) due to the pandemic ${ }^{(22)}$.

Ratifying the results of this research, a study carried out in Australia showed that children and adolescents with disabilities and their families are facing significant challenges during the pandemic. The authors suggest that a range of other inequalities are also exacerbated by such events and that this group was one of the most marginalized in Australian society before the pandemic 
and now faces significant daily injustices. These individuals are at greater risk in a pandemic context - both from the disease and from social and political responses to its control(23).

National studies demonstrate that the daily life of CSHCN families is marked by efforts and difficulties that transcend the child's clinical fragility, such as social vulnerability, low income, and low level of education of caregivers ${ }^{(24-25)}$. Socioeconomic factors have hindered the access of these patients and their families to health services, causing inequities in access ${ }^{(26-27)}$.

Thus, it is observed that there are numerous challenges experienced by $\mathrm{CSHCN}$ in facing the new coronavirus pandemic, as they are a public that live in a situation of social vulnerability. According to a Brazilian research, they are still without access to basic rights, increasing the risks of social vulnerability due to the quarantine imposed by the global epidemiological situation. Therefore, the pandemic can change the reality experienced by children for the worse, in view of the closure of schools and restrictions on travel(28).

It is important to note that, before COVID-19, families of children with disabilities, such as those in this study, have historically been marginalized, and this situation only worsened during the pandemic, as they had more health problems and unmet needs.

Families had to organize quickly to accommodate major changes in access to support, services, and supplies. Their caregivers must now adapt to increasing stressors, such as the lack of access to necessary therapies, medical supplies, and nursing care ${ }^{(29)}$.

On the other hand, the pandemic revealed new forms of care, specifically, teleconsultations. A reflective Brazilian study confirms that one of the viable strategies for the continuation of assistance to people with chronic diseases would be that of teleconsultation. This teleconsultation model, which avoids personal contact between doctors and patients, is useful in the current epidemic situation, bringing benefits for maintaining continuity of care ${ }^{(30)}$.

In addition, social distancing, one of the health measures adopted to prevent contamination, can dramatically affect rehabilitation interventions, especially when children need physical interaction with their therapists, as is the case with CSHCN. In this context, telehealth solutions, such as telerehabilitation, are considered valid. Remote consultations can bring the parents closer and help them to understand the problems, maintaining the quality of care $\mathrm{e}^{(31)}$.

In summary, the pandemic of the new coronavirus has evidenced problems for continuity of care for CSHCN, such as difficult access to essential resources in health services. In the case of teleconsultations, families need access to the internet, ability to use a smartphone, which must be considered when evaluating health services. In addition, the need for emotional support from caregivers must be included as a demand for professionals, who, in the midst of feelings such as fears and uncertainties regarding the discontinuity of formal health care services, seek resources in themselves and in the community to face that situation and take care of their child.

Thus, ensuring continuity of care for CSHCN during the pandemic has been a major challenge for health systems. However, it is necessary to institute new forms and reformulate old ideas to offer health care to this population, such as teleconsultation. These resources can mitigate the future losses that these children may have in their development, as well as establish a closer bond with the caregivers and minimize situations of emotional stress in daily care with the CSHCN.

\section{Study limitations}

As a limitation of this study, the participation of only mothers of CSHCN who attended a physiotherapy service stands out, as we consider them to be those who were making more frequent use of health services, however, it would be necessary to expand this study to the population using health services, in general, with a view to a more comprehensive understanding of the phenomenon. However, this limitation did not compromise the quality of the obtained data.

\section{Contributions to the field of nursing, health, and public policies}

This research contributes to the understanding of the reality experienced by CSHCN and their caregivers in the midst of a health crisis, with substantial restrictions on the continuity of care. The understanding of this phenomenon should contribute to the improvement of assistance to these children and their families by health professionals and services throughout the pandemic. The active search by the family health team, including these children's nurses and their families, with guidance that can be offered at home, can contribute to minimize the doubts, fears, and uncertainties reported by the caregivers in this study.

It is hoped that further research can better explore the needs and desires of families of CSHCN during the COVID-19 pandemic, since this public is still invisible in public health policies.

\section{FINAL CONSIDERATIONS}

The caregivers' discourse revealed problems in the continuity of care for CSHCN due to the COVID-19 pandemic. It is considered that health care practices should be rethought in times of pandemic, aiming to offer remote care to these children in order to minimize the consequences of the suspension of essential services and health monitoring for this public.

We emphasize that CSHCN should be a focus of assessment and intervention in this pandemic period, including active monitoring and home visits to mitigate the negative consequences of social isolation and the discontinuity of health care.

For this reason, remote care (such as teleconsultations) needs to be strengthened in times of pandemic, and family members and caregivers need emotional support so that they can both overcome the adversities of that moment and maintain, at home, the necessary care for CSHCN.

\section{REFERENCES}

1. Bhuiyan MU, Stiboy E, Hassan MdZ, Chan M, Islam MdS, Haider N, et al. Epidemiology of COVID-19 infection in young children under five years: a systematic review and meta-analysis. Vaccine. 2021;39(4):667-77. https://doi.org/10.1038/s41562-020-0928-4 
2. Werneck GL, Carvalho MS. A pandemia de COVID-19 no Brasil: crônica de uma crise sanitária anunciada. Cad Saúde Pública. 2020;36(5):e00068820. https://doi.org/10.1590/0102-311X00068820

3. Sohrabi C, Alsafi Z, O'Neill N, Khan M, Kerwan A, Al-Jabir A, et al. World Health Organization declares global emergency: a review of the 2019 novel coronavirus (COVID-19). Int J Surg. 2020;76:71-6. https://doi.org/10.1016/j.ijsu.2020.02.034

4. McPherson M, Arango P, Fox H, Lauver C, McManus M, Newacheck PW, et al. A new definition of children with special health care needs. Am Acad Pediatr. 1998;102(1):137-41. https://doi.org/10.1542/peds.102.1.137

5. Gupta J, Madaan P, Gulati S. COVID-19: Implications for Children with Special Needs. J ReAttach Ther Developm Diversit. 2020;3(1):1-3. https://doi.org/10.26407/2020jrtdd.1.31

6. Silveira AD, Neves ET. Crianças com necessidades especiais de saúde: tendências das pesquisas em enfermagem. Rev Enferm UFSM. 2011;1(2):254. https://doi.org/10.5902/217976922500

7. Zanello E, Calugi S, Rucci P, Pieri G, Vandini S, Faldella G, et al. Continuity of care in children with special healthcare needs: a qualitative study of family's perspectives. Ital J Pediatr. 2015;41(1):7. https://doi.org/10.1186/s13052-015-0114-x

8. Minayo MCS. O desafio do conhecimento: pesquisa qualitativa em saúde. 14. ed. São Paulo: Hucitec, 2014.

9. Tong A, Sainsbury P, Craig J. Consolidated criteria for reporting qualitative research (COREQ): a 32-item checklist for interviews and focus groups. Int J Qual Health Care. 2007;19(6):349-57. https://doi.org/10.1093/intqhc/mzm042

10. Instituto Brasileiro de Geografia e Estatística. Censo 2010[Internet]. 2011 [cited 2021 Feb 12]. Available from: https://cidades.ibge.gov.br/ brasil/ce/senador-pompeu/panorama

11. Cadastro Nacional de Estabelecimentos de Saúde - CnesWeb. Estabelecimento de Saúde do Município: Senador Pompeu[Internet]. 2018 [cited 2021 Feb 10]. Available from: http://cnes2.datasus.gov.br/Lista_Es_Municipio.asp?VEstado=23\&VCodMunicipio=231270\&NomeEstad $\mathrm{o}=$ CEARA.

12. Presidência da República (BR). Lei n.8.069, de 13 de julho de 1990. Dispõe sobre o Estatuto da Criança e do Adolescente e dá outras providências [Internet]. 1990[cited 2021 Feb 25]. Available from: http://www.planalto.gov.br/ccivil_03/leis/l8069.htm

13. Bardin, L. Análise de Conteúdo. São Paulo: Edições 70, 2011.

14. Cunha EM, Giovanella L. Longitudinalidade/continuidade do cuidado: identificando dimensões e variáveis para a avaliação da Atenção Primária no contexto do sistema público de saúde brasileiro. Ciênc Saúde Colet. 2011;16(suppl 1):1029-42. https://doi.org/10.1590/ S1413-81232011000700036

15. Grumi S, Provenzi L, Gardani A, Aramini V, Dargenio E, Naboni C, et al. Rehabilitation services lockdown during the COVID-19 emergency: the mental health response of caregivers of children with neurodevelopmental disabilities. Disabil Rehabil. 2021;43(1):27-32. https://doi.org $/ 10.1080 / 09638288.2020 .1842520$

16. Provenzi L, Borgatti R. Potentials of telerehabilitation for families of children with special health care needs during the Coronavirus Disease 2019 Emergency. JAMA Pediatr. 2021;175(1):105. https://doi.org/10.1001/jamapediatrics.2020.2351

17. Schiariti V. The human rights of children with disabilities during health emergencies: the challenge of COVID-19. Developm Med Child Neurol. 2020;62(6):661-661. https://doi.org/10.1111/dmcn.14526

18. Estrela FM, Cruz MA, Gomes NP, Oliveira MAS, Santos RDS, Magalhães JRF, et al. COVID-19 e doenças crônicas: impactos e desdobramentos frente à pandemia. Rev Baiana Enferm. 2020;34:e36559. https://doi.org/10.18471/rbe.v34.36559

19. Prime $\mathrm{H}$, Wade M, Browne DT. Risk and resilience in family well-being during the COVID-19 pandemic. Am Psychol. 2020;75(5):631-43. https://doi.org/10.1037/amp0000660

20. Aishworiya R, Kang YQ. Including Children with Developmental Disabilities in the Equation During this COVID-19 Pandemic. J Autism Dev Disord. 2020;1-4. https://doi.org/10.1007/s10803-020-04670-6

21. Dickinson H, Yates S. (2020) More than isolated: the experience of children and young people with disability and their families during the COVID-19 pandemic. Report prepared for Children and Young People with Disability Australia (CYDA), Melbourne. [cited 2021 Feb 23]. Available from: https://www.cyda.org.au/resources/details/161/ more-than-isolated-the-experience-of-children-and-young-people-with-disability-and-their-families-during-the-covid-19-pandemic.

22. Baumbusch, JL, Lamden-Bennett, SR, Lloyd JEV. The Impact of COVID-19 on British Columbia's Children with Medical Complexity and their Families. Vancouver, BC: Supporting Progressive Inclusive Child-centered Education (SPICE) Lab, School of Nursing, University of British Columbia [Internet]. 2020[cited 2021 Feb 08]. Available from: https://open.library.ubc.ca/soa/clRcle/collections/ facultyresearchandpublications/52383/items/1.0395118

23. Yates S, Dickinson H. Navigating complexity in a global pandemic: the effects of COVID-19 on children and young people with disability and their families in Australia. Public Admin Rev. 2021;puar.13352. https://doi.org/10.1111/puar.13352

24. Okido ACC, Neves ET, Cavicchioli GN, Jantsch LB, Pereira FP, Lima RAG. Factors associated with family risk of children with special health care needs. Rev Esc Enferm USP. 2018;52:e03377. https://doi.org/10.1590/S1980-220X2017048703377

25. Neves ET, Cabral IE. A fragilidade clínica e a vulnerabilidade social das crianças com necessidades especiais de saúde. Rev Gaúcha Enferm[Internet]. 2008 [cited 2021 Feb 11];29(2):182-90. Available from: https://seer.ufrgs.br/RevistaGauchadeEnfermagem/article/ view/5533/3150 
26. Kuo DZ, Goudie A, Cohen E, Houtrow A, Agrawal R, Carle AC, et al. Inequities in health care needs for children with medical complexity. Health Affairs. 2014;33(12):2190-8. https://doi.org/10.1377/hlthaff.2014.0273

27. Góes FGB, Cabral IE. Discursos sobre cuidados na alta de crianças com necessidades especiais de saúde. Rev Bras Enferm. 2017;70(1):163-71. https://doi.org/10.1590/0034-7167-2016-0248

28. Christoffel MM, Gomes ALM, Souza TV, Ciuffo LL. Children's (in)visibility in social vulnerability and the impact of the novel coronavirus (COVID-19). Rev Bras Enferm. 2020;73(suppl 2):e20200302. https://doi.org/10.1590/0034-7167-2020-0302

29. Houtrow A, Harris D, Molinero A, Levin-Decanini T, Robichaud C. Children with disabilities in the United States and the COVID-19 pandemic. McLaughlin M, Vercler C, (Org.). PRM. 23 de novembro de 2020;13(3):415-24. https://doi.org/10.3233/PRM-200769

30. Caetano R, Silva AB, Guedes ACCM, Paiva CCN, Ribeiro GR, Santos DL, et al. Desafios e oportunidades para telessaúde em tempos da pandemia pela COVID-19: uma reflexão sobre os espaços e iniciativas no contexto brasileiro. Cad Saúde Pública. 2020;36(5):e00088920. https://doi.org/10.1590/0102-311X00088920

31. Provenzi L, Grumi S, Gardani A, Aramini V, Dargenio E, Naboni C, et al. Italian parents welcomed a telehealth family-centred rehabilitation programme for children with disability during COVID-19 lockdown. Acta Paediatr. 2021;110(1):194-6. https://doi.org/10.1111/apa.15636 